\title{
IMPLEMENTASI MODEL PEMBELAJARAN COMPETENCE BASED TRAINING (CBT) BERBASIS KARAKTER DALAM PRAKTIK PEMESINAN FRAIS
}

\author{
Paryanto $^{1}$, Asnawi $^{2}$ \\ 1,2 Jurusan Pendidikan Teknik Mesin, Fakultas Teknik, Universitas Negeri Yogyakarta \\ paryanto@uny.ac.id
}

\begin{abstract}
The purpose of this study was to determine the impact of CBT Learning Model based on character in the milling machine practice, in relation with: (1) changes in attitude and behavior of the students, and (2) improvement of students' academic achievement. This research is a classroom action research. The research subjects were the B1 group of 3rd semester students of Mechanical Engineering Education Bachelor Degree program enrolled in Milling Machine Process course. Data were collected by means of observation and tests. Analysis of the data were carried out using quantitative-descriptive techniques. Results of this study are: (1) attitude and behavior of the students were improved with an average of 30.66\%, and (2) students' achievement were improved by an average of $17.55 \%$.
\end{abstract}

Keywords: character based, competence based training, milling practice

\begin{abstract}
ABSTRAK
Tujuan penelitian ini adalah untuk mengetahui dampak penerapan Model Pembelajaran CBT Berbasis Karakter dalam praktik pemesinan frais, yang terkait dengan: (1) perubahan sikap dan perilaku mahasiswa; (2) peningkatan prestasi belajar mahasiswa. Jenis penelitian ini merupakan penelitian tindakan kelas. Subjek penelitian adalah mahasiswa semester 3 Program Studi S1 Pendidikan Teknik Mesin yang mengikuti mata kuliah Proses Pemesinan Frais kelas B1. Pengumpulan data menggunakan teknik observasi dan tes. Analisis data menggunakan teknik deskriptif kuantitatif. Hasil penelitian ini adalah: (1) sikap dan perilaku mahasiswa mengalami peningkatan yaitu rata-rata sebesar 30,66\%; (2) prestasi belajar mahasiswa juga mengalami peningkatan rata-rata sebesar $17,55 \%$.
\end{abstract}

Kata kunci: CBT berbasis karakter, pemesinan frais

\section{PENDAHULUAN}

Pendidikan yang dilaksanakan di seluruh Negara Indonesia mestinya berpedoman pada aturan-aturan yang berlaku. Dalam UU N0. 20 Pasal 3 tahun 2003 tantang Sistem Pendidikan Nasional, pendidikan nasional harus mengembangkan kemampuan dan membentuk karakter serta peradaban bangsa yang bermartabat dalam rangka mencerdaskan kehidupan bangsa, bertujuan untuk berkembangnya potensi peserta didik agar menjadi manusia yang beriman dan bertakwa kepada Tuhan Yang Maha Esa, berakhlak mulia, sehat, berilmu, cakap, kreatif, mandiri dan menjadi warga negara yang demokratis serta bertanggung jawab. Sangat mulia sebetulnya rumusan tersebut, namun berdasarkan kenyataan yang terjadi akhir-akhir ini sangat menyita keprihatinan kita. Dimana sekarang ini rasa sopan santun antara yang muda dengan yang tua sudah mulai luntur. Rasa hormat murid dengan gurunya sudah mulai berkurang. Banyak terjadi tawuran antar pelajar bahkan antar mahasiswa.

Fenomena negatif tersebut juga dirasakan terjadi di Jurusan Pendidikan Teknik Mesin FT UNY, khususnya yang terjadi dalam proses pembelajaran praktik pemesinan frais. Dalam proses pembelajaran praktik, sikap mahasiswa jauh dari yang semestinya dijalankan. Masih banyak dijumpai mahasiswa yang kurang disiplin, yaitu sering datang terlambat dan dalam bekerja tidak sesuai dengan prosedur yang benar. Seringkali mahasiswa meninggalkan ruang praktik pada 
saat pembelajaran sedang berlangsung. Kepedulian mereka terhadap kebersihan lingkungan maupun perawatan alat dan mesin yang mereka gunakan selama praktik juga sangat kurang, sehingga beberapa komponen mesin dan peralatan sudah mengalami kerusakan. Sifat teliti dan ketelatenan mahasiswa masih sangat kurang, hal ini terlihat jelas dari benda kerja hasil praktik memiliki dimensi yang menyimpang jauh dari yang semestinya. Disamping beberapa hal tersebut, kemampuan akademis mahasiswa ternyata $75 \%$ masih termasuk dalam kategori rendah. Hal ini dapat dilihat pada saat penyusunan Work Preparation Sheet, mereka mengalami kesulitan dalam penentuan parameter pemotongan setiap job yang harus mereka kerjakan. Disamping itu, akhir-akhir ini mahasiswa kurang memiliki rasa hormat kepada dosen, seringkali mahasiswa bersikap tidak sopan terhadap dosen.

Berdasarkan kenyataan tersebut, menjadi tanggung jawab dunia pendidikan khususnya pendidikan vokasi tak terkecuali bagi Jurusan Pendidikan Teknik Mesin FT UNY, untuk menciptakan lulusan yang selain memiliki kompetensi akademik juga berkarakter unggul. Salah satu aspek yang sering diremehkan namun sebetulnya sangat urgen adalah perbaikan sikap, karakter dan mental mahasiswa. Untuk mengatasi permasalahan terkait sikap dan mental mahasiswa tersebut, maka dalam penelitian ini akan mencoba mengimplementasikan nilai-nilai karakter dalam proses pembelajaran Praktik Pemesinan Frais. Salah satu upaya untuk mengimplementasikan nilai-nilai karakter dalam pembelajaran berbasis kompetensi adalah dengan menerapkan model pembelajaran Competence Based Training (CBT) berbasis karakter.

Model pembelajaran Competence Based Training (CBT) berbasis karakter merupakan model pembelajaran yang telah dikembangkan oleh peneliti (Paryanto, dkk). Dalam model pembelajaran ini sekaligus menyisipkan nilainilai karakter ke dalam proses pembelajaran yang sedang dijalankan. Sehingga dengan menerapkan model pembelajaran Competence Based Training (CBT) berbasis karakter ini diharapkan mampu membekali mahasiswa dengan kompetensi akademik serta sekaligus membentuk karakter mahasiswa yaitu tangguh (mandiri), jujur, disiplin, dan kerja sama. Sehingga diharapkan setelah mengimplementasikan nilai-nilai karakter tersebut, mahasiswa akan berkarakter baik yaitu memiliki sikap dan mental yang baik, yang pada akhirnya diharapkan dapat meningkatkan prestasi belajar mahasiswa.

$$
\text { Berdasarkan latar belakang }
$$

permasalahan di atas, maka permasalahan yang ingin dijawab melalui penerapan Model Pembelajaran CBT Berbasis Karakter adalah bagaimanakah perubahan sikap dan perilaku mahasiswa, serta peningkatan prestasi belajar mahasiswa. Sesuai permasalahan tersebut, maka tujuan penelitian ini untuk mengetahui perubahan sikap dan perilaku serta prestasi belajar mahasiswa setelah menerapkan Model Pembelajaran CBT Berbasis Karakter dalam proses pembelajaran Praktik Pemesinan Frais.

Pembelajaran berbasis kompetensi adalah pembelajaran yang dilakukan dengan orientasi pencapaian kompetensi peserta didik. Sehingga muara akhir hasil pembelajaran adalah meningkatnya kompetensi peserta didik yang dapat diukur dalam pola sikap, pengetahuan, dan keterampilannya (Sidik Purnomo : http://kidispur.blogspot.com). Konsep pembelajaran berbasis kompetensi mensyaratkan dirumuskannya secara jelas kompetensi yang harus dimiliki atau ditampilkan peserta didik setelah mengikuti kegiatan pembelajaran. Dengan tolok ukur pencapaian kompetensi maka dalam kegiatan pembelajaran peserta didik akan terhindar dari mempelajari materi yang tidak perlu yaitu materi yang tidak menunjang tercapainya penguasaan kompetensi.

Lebih lanjut dalam aspek pembelajaran, Depdiknas (2002) menyatakan bahwa pembelajaran berbasis kompetensi memiliki lima karakteristik sebagai berikut: (1) 
Menekankan pada ketercapaian kompetensi peserta didik baik secara individu maupun klasikal; (2) Berorientasi pada hasil belajar dan keragaman; (3) Penyampaian dalam pembelajaran menggunakan pendekatan dan metode yang bervariasi; (4) Sumber belajar bukan hanya dosen tetapi juga sumber belajar lainnya yang memenuhi unsur edukatif; (5) Penilaian menekankan pada proses dan hasil belajar dalam upaya penguasaan atau pencapaian kompetensi.

Sejalan dengan hal tersebut, menurut Gonczi (1998: 38), karakteristik penting yang terdapat pada model-model pendidikan berbasis kompetensi, di antaranya:

1. Adanya daftar kompetensi yang terdokumentasikan disertai dengan standar dan kondisi khusus untuk masing-masing kompetensi.

2. Setiap saat siswa dapat dinilai pencapaian kompetensinya manakala telah siap.

3. Pembelajaran berlangsung dengan format modul yang berkaitan dengan masingmasing kompetensi.

4. Penilaian berdasarkan standar tertentu dalam pernyataan-pernyataan kompetensi.

5. Sebagian besar penilaian berdasarkan keterampilan yang didemontrasikan secara nyata.

6. Siswa dapat memperoleh pengecualian dari bagian pembelajaran dan melanjutkan ke unit kerja berikutnya berdasarkan kompetensi yang telah tercapai.

7. Hasil belajar siswa dicatat dan dilaporkan dalam pernyataan-pernyataan kompetensi

Karakteristik pembelajaran berbasis kompetensi tersebut menuntut dosen untuk selalu berinovasi dan berimprovisasi dalam menentukan metode dan strategi pembelajaran yang sesuai. Dalam proses pembelajaran yang banyak mengalami kendala, dosen dituntut untuk mencari dan menemukan pendekatan baru yang efektif dan efisien. Namun pada saat ini guru/dosen dinilai masih kurang memilki bekal pengetahuan didaktik, metodik, materi dan kreativitas dalam pembelajaran (Dedi
Supriyadi, 2001). Dalam kondisi seperti ini maka pemilihan model pembelajaran harus disesuaikan dengan kemampuan dosen, dan tidak memberatkan pekerjaan dosen.

Menurut Darmiyati Zuhdi (2009: 16) ada enem aspek karakter atau nilai yang dapat diintegrasikan dalam proses perkuliahan, yaitu ketaatan beribadah, kejujuran, tanggungjawab, kepedulian, kerjasama, dan hormat pada orang/pihak lain. Sedangkan menurut Marihot Manullang secara lebih rinci, menyebutkan nilai/ciri-ciri karakter SDM yang kuat meliputi (1) religious, yaitu sikap hidup dan kepribadian yang taat beribadah, jujur, terpercaya, dermawan, saling tolong menolong, dan toleran; (2) moderat, yaitu memiliki sikap hidup yang tidak radikal dan tercermin dalam kepribadian yang tengahan antara individu dan sosial, berorientasi materi dan rohani serta mampu hidup dan kerjasama dalam kemajemukan; (3) cerdas, yaitu memiliki sikap hidup dan kepribadian yang rasional, cinta ilmu, terbuka, dan berpikiran maju; dan (4) mandiri, yaitu memiliki sikap hidup dan kepribadian merdeka, disiplin tinggi, hemat, menghargai waktu, ulet, wirausaha, kerja keras dan memiliki cinta kebangsaan yang tinggi tanpa kehilangan orientasi nilai-nilai kemanusiaan universal dan hubungan antarperadaban bangsa-bangsa.

Pada intinya bentuk karakter apa pun yang dirumuskan tetap harus berlandaskan pada nilai-nilai universal. Oleh karena itu, pendidikan yang mengembangkan karakter adalah bentuk pendidikan yang bisa membantu mengembangkan sikap etika, moral dan tanggung jawab, memberikan kasih sayang kepada anak didik dengan menunjukkan dan mengajarkan karakter yang bagus. Hal itu merupakan usaha intensional dan proaktif dari sekolah, masyarakat dan negara untuk mengisi pola pikir dasar anak didik, yaitu nilai-nilai etika seperti menghargai diri sendiri dan orang lain, sikap bertanggung jawab, integritas, dan disiplin diri. Hal itu memberikan solusi jangka panjang yang mengarah pada isu-isu moral, etika dan akademis yang merupakan concern 
dan sekaligus kekhawatiran yang terus meningkat di dalam masyarakat.

Model pembelajaran CBT berbasis karakter merupakan hasil pengembangan model pembelajaran yang telah dilaksanakan oleh peneliti (Paryanto, dkk) pada penelitian sebelumnya. Dalam model pembelajaran ini, dikembangkan dari model pembelajaran CBT, dimana dalam proses pembelajarannya dimodifikasi sedemikian rupa sehingga mampu menanamkan aspek atau nilai-nilai karakter kepada mahaiswa. Sehingga dengan dilaksanakannya model pembelajaran ini, disamping mampu membekali mahasiswa dengan kompetensi akademik juga mampu membentuk karakter mahasiswa yang unggul. Tahapan model pembelajaran CBT berbasis karakter dapat dilihat pada Gambar 1.

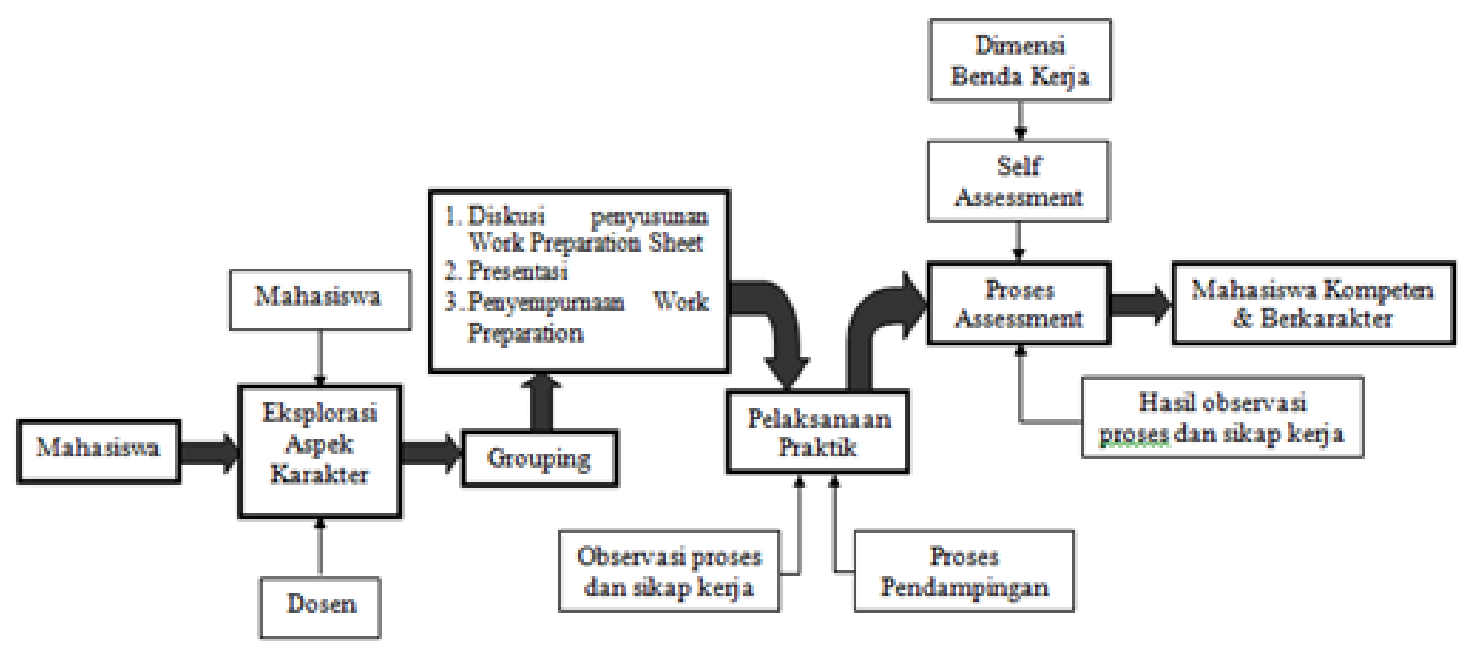

Gambar 1. Tahapan model pembelajaran CBT berbasis karakter

Input

Input atau masukan adalah mahasiswa atau dapat juga siswa SMK yang akan mengikuti pembelajaran praktik pemesinan. Model pembelajaran ini dapat diterapkan dalam setiap pembelajaran praktik pemesinan tanpa membedakan tingkat atau semester berapa.

\section{Eksplorasi nilai karakter}

Tahapan selanjutnya adalah proses eksplorasi nilai karakter disesuaikan dengan karakter kerja pemesinan, yaitu kemampuan membaca gambar kerja, memilih alat kerja dengan cerdas, menentukan langkah/prosedur kerja, menentukan kriteria kerja, menggunakan alat kerja dengan terampil, merawat alat kerja, menjaga sikap kerja, menjaga lingkungan kerja, mentaati keselamatan kerja, disiplin kerja, mampu sebagai tim kerja, kepatuhan akan peraturan kerja. Pada proses eksplorasi ini dilaksanakan dengan metode diskusi, dimana mahasiswa diminta untuk mengidentifikasi aspek atau nilai karakter apa saja yang harus dijalankan bilamana mereka melaksanakan praktik pemesinan. Hal ini dimaksudkan apabila mahasiswa sudah mampu menggali atau mengidentifikasi nilai karakter, maka tentunya mereka telah memiliki kesadaran untuk melaksanakan nilai-nilai karakter tersebut dalam proses pembelajaran praktik. Dengan demikian apabila mahasiswa melaksanakan praktik dengan prosedur yang benar, sehingga dengan sendirinya mahasiswa tersebut telah melaksanakan nilai karakter. Pada tahapan ini, peran dosen adalah membantu mengarahkan dan menjelaskan setiap nilai karakter yang dapatdiintegrasikan dalam pembelajaran praktik pemesinan.

\section{Grouping}

Pembentukan grup dilaksanakan oleh dosen dengan keanggotaan kelompok diambil 
secara acak. Grup dibentuk agar mahasiswa saling bekerjasama terutama dalam proses penyusunan Work Preparation (perencanaan kerja). Maksud pembentukan grup ini adalah mambiasakan mahasiswa untuk memiliki rasa toleran dan kerja sama. Setelah dibentuk kelompok, maka dosen dapat membagi job kerja masing-masing kelompok, untuk selanjutnya dipelajari terlebih dahulu oleh mahasiswa, kemudian disusun Work

Preparation.

\section{Penyusunan Work Preparation Sheet (lembar} perencanaan kerja)

Sebelum melaksanakan praktik, maka setiap mahasiswa diwajibkan menyusun Work Preparation Sheet (WPS) atau lembar perencanaan kerja dari setiap job praktik. Secara umum WPS berisikan urutan langkah kerja, alat dan mesin yang digunakan, perhitungan parameter pemotongan, prediksi waktu pekerjaan, alat dan tindakan keselamatan kerja. Dalam hal ini, WPS disusun secara berkelompok dengan harapan mahasiswa mampu bekerjasama dalam tim. WPS harus disusun secara runtut dan benar, sehingga mampu menjadi pedoman mahasiswa dalam melaksanakan praktik. Setelah WPS selesai disusun oleh setiap kelompok, kemudian dipresentasikan dalam kelas sehingga kelompok lain dapat memberikan masukan terhadap WPS yang dipresentasikan oleh kelompok lain tersebut. Dalam tahapan ini dosen berperan sebagai fasilitator dalam diskusi yang dilaksanakan dan bersama mahasiswa menyempurnakan WPS yang mereka susun. Dalam tahapan ini nilai karakter yang diintegrasikan adalah mampu bekerja sama dalam tim, berani mengungkapkan pendapat, dan toleransi.

\section{Pelaksanaan Pembelajaran Praktik}

Tahapan selanjutnya adalah masuk dalam pembelajaran praktik. Mahasiswa melaksanakan praktik dengan berpedoman pada langkah kerja atau prosedur kerja sesuai dengan WPS yang telah disusun. Sebagai salah satu alternatif job yang dapat dipraktikan adalah job yang bersifat collaborative skill, artinya sebuah job praktik yang terdiri dari beberapa komponen yang kemudian dipasangkan satu dengan lainnya. Sehingga job ini dapat dikerjakan secara berkelompok dimana masingmasing mahasiswa mendapatkan tugas untuk mengerjakan satu komponen. Dalam hal ini disamping mahasiswa harus bekerja sama, juga harus memiliki rasa untuk saling menyesuaikan atau toleransi sehingga komponen yang mereka kerjakan dapat dipasangkan dengan baik menjadi satu unit alat. Dalam pelaksanaan kegiatan praktik ini, dapat diamati proses kerja mahasiswa dan proses integrasi nilai karakter yang dilaksanakan oleh setiap mahasiswa dengan menggunakan lembar observasi. Peran dosen dalam kegiatan praktik adalah selalu memberikan pembimbingan dan pendampingan, sehingga mahasiswa segera mendapatkan solusi apabila mereka menemui kendala dalam melaksanakan praktik.

\section{Proses Assessment}

Tahapan terakhir adalah proses assessment, yang dalam hal ini terdiri dari beberapa komponen penilaian, yaitu penilaian proses kerja, dimensi benda kerja dan hasil pengamatan aspek karakter mahasiswa. Untuk menanamkan rasa kejujuran pada mahasiswa, maka proses assessment dilakukan secara self assessment yaitu mahasiswa dipersilahkan memberikan point pengukuran terhadap dimensi benda kerja yang telah mereka kerjakan dengan menggunakan lembar assessment. Meskipun demikian dosen juga melakukan pengukuran terhadap dimensi benda kerja yang telah dikerjakan mahasiswa, sehingga dapat mengecek kebenaran dari pengukuran yang telah dilakukan oleh mahasiswa. Kemudian dosen memberikan penilaian atas hasil pembelajaran praktik mahasiswa.

\section{METODE}

Jenis penelitian ini merupakan penelitian tindakan kelas model Kemmis \& Tagart 
(gambar 2), yaitu suatu penelitian yang bersifat kolaboratif antara pendidik, peneliti dan peserta didik berdasarkan permasalahan yang muncul dalam kegiatan pembelajaran di jurusan Pendidikan Teknik Mesin. Penelitian ini dilaksanakan selama 3 bulan mulai bulan September hingga November 2016. Penelitian ini mengambil tempat di Jurusan Pendidikan Teknik Mesin FT UNY.

Subjek penelitian adalah mahasiswa semester 3 Program Studi S1 Pendidikan Teknik Mesin yang mengikuti mata kuliah Proses Pemesinan Frais kelas B1, berjumlah 18 orang. Pengumpulan data menggunakan teknik observasi dan tes. Teknik analisis yang akan digunakan adalah teknik analisis deskriptif kuantitatif.

\section{HASIL DAN PEMBAHASAN}

Penelitian ini telah dilaksanakan selama tiga siklus. Hasil penelitian yang telah didapatkan adalah sebagai berikut:

Siklus 1

Rincian tindakan dalam rangka implementasi nilai karakter untuk siklus 1 adalah sebagai berikut:

\section{Rancangan Perencanaan}

a. Dosen mempersiapkan materi/job praktik pemesinan frais yang akan diberikan pada mahasiswa.

b. Dosen menjelaskan karakter kerja praktik pemesinan frais.

2. Rancangan Tindakan

a. Dosen membentuk kelompok yang setiap kelompoknya terdiri dari 3-4 mahasiswa.

b. Dosen mempersilahkan mahasiswa berdiskusi dalam kelompoknya menyusun work preparation sheet (WPS) job masing-masing.

c. Dosen memberikan waktu kepada masing-masing kelompok mempresentasikan WPS yang telah disusun. d. Dosen memberikan pengarahan untuk menyempurnakan WP yang telah disusun mahasiswa.

e. Dosen mempersilahkan mahasiswa untuk melaksanakan praktik, dengan arahan untuk selalu bekerjasama agar benda kerja yang dihasilkan presisi dan dapat dipasangkan satu dengan lainnya.

f. Pada akhir siklus dosen mengadakan penilaian benda kerja yang telah dibuat dengan melibatkan mahasiswa dalam proses tersebut (dengan menggunakan lembar self assessment).

3. Rancangan Pengamatan

a. Peneliti mengamati sikap dan perilaku mahasiswa selama proses pembelajaran (mulai dari proses penjelasan, diskusi, hingga praktik).

b. Mengamati aktivitas mahasiswa pada saat proses self assessment.

Hasil pengamatan sikap dan perilaku mahasiswa selama proses pembelajaran siklus 1 dapat dilihat dalam Tabel 1.

Tabel 1. Hasil pengamatan sikap dan perilaku mahasiswa pada siklus 1

\begin{tabular}{clcc}
\hline No & $\begin{array}{l}\text { Sikap dan perilaku } \\
\text { Mahasiswa }\end{array}$ & $\begin{array}{l}\text { Jumlah } \\
\text { Mahasiswa }\end{array}$ & $\begin{array}{l}\text { Persentase } \\
(\%)\end{array}$ \\
\hline 1 & Disiplin & 7 & 38 \\
2 & Tangguh/mandiri & 5 & 27,7 \\
3 & Kerja sama & 6 & 33,33 \\
4 & Jujur & 6 & 33,33 \\
\hline \multicolumn{2}{r}{ Rerata } & & 33,075 \\
\hline
\end{tabular}

Berdasarkan hasil penilaian benda kerja yang telah dibuat, nilai yang didapatkan juga belum memuaskan, hasil selengkapnya dapat dilihat dalam Tabel 2.

Tabel 2. Hasil penilaian benda kerja hasil praktik pada siklus 1

\begin{tabular}{ccc}
\hline No & Kelompok & Nilai Rata-Rata \\
\hline 1 & I & 60 \\
2 & II & 65 \\
3 & III & 62 \\
4 & IV & 65 \\
5 & V & 68 \\
\hline & Rerata & 64 \\
\hline
\end{tabular}




\section{Refleksi}

Langkah selanjutnya dilakukan refleksi, berdasarkan hasil pengamatan pada siklus 1 tersebut, tampak bahwa sikap dan perilaku mahasiswa masih dalam kondisi yang rendah. Mahasiswa belum fokus dalam bekerja, masih banyak dijumpai mahasiswa yang menunggu temannya untuk mengerjakan dahulu, dengan kata lain mahasiswa kurang percaya diri dan tingkat kemandiriannya masih rendah. Sepertinya mahasiswa belum menjiwai aspekaspek karakter yang diintegrasikan. Jika dilihat dari penilaian benda kerja hasil praktik, maka hasilnya juga belum memuaskan.

Untuk mengatasi hal tersebut, agar pada siklus 2 terjadi perubahan positif, maka sebelum mahasiswa menyusun WPS, diadakan semacam kegiatan diskusi untuk eksplorasi aspek karakter yang dapat diintegrasikan dalam pembelajaran praktik menurut mahasiswa.

\section{Siklus 2}

Rincian tindakan pada siklus 2:

\section{Rancangan Perencanaan}

a. Dosen mempersiapkan materi/job praktik selanjutnya yang akan diberikan pada mahasiswa.

b. Dosen menjelaskan pembelajaran dimulai dengan kegiatan diskusi.

2. Rancangan Tindakan

a. Dosen memandu kegiatan diskusi yang bertujuan untuk eksplorasi aspek karakter ang dapat diintegraskan pada pembelajaran praktik, menurut mahasiswa.

b. Dosen menghimbau kepada mahasiswa untuk konsekuen dalam melaksanakan aspek karakter yang sudah dieksplorasi, dalam pelaksanaan praktik.

c. Dosen mempersilahkan mahasiswa untuk melaksanakan praktik, dengan arahan untuk selalu berpedoman pada WP yang telah disusun dan selalu bekerjasama agar benda kerja yang dihasilkan presisi dan dapat dipasangkan satu dengan lainnya. d. Pada akhir siklus dosen mengadakan penilaian benda kerja yang telah dibuat dengan melibatkan mahasiswa dalam proses tersebut (dengan menggunakan lembar self assessment).

3. Rancangan Pengamatan

a. Peneliti mengamati sikap dan perilaku mahasiswa selama proses pembelajaran.

b. Mengamati aktivitas mahasiswa pada saat proses self assessment.

Hasil pengamatan sikap dan perilaku mahasiswa selama proses pembelajaran siklus 2 dapat dilihat dalam Tabel 3.

Tabel 3. Hasil pengamatan sikap dan perilaku mahasiswa pada siklus 2

\begin{tabular}{clcc}
\hline No & $\begin{array}{l}\text { Sikap dan perilaku } \\
\text { Mahasiswa }\end{array}$ & $\begin{array}{l}\text { Jumlah } \\
\text { Mahasiswa }\end{array}$ & $\begin{array}{c}\text { Persentase } \\
(\%)\end{array}$ \\
\hline 1 & Disiplin & 13 & 72,22 \\
2 & Tangguh/mandiri & 15 & 83,33 \\
3 & Kerja sama & 16 & 88,89 \\
4 & Jujur & 15 & 83,33 \\
\hline \multicolumn{2}{r}{ Rerata } & 81,94 \\
\hline
\end{tabular}

Hasil penilaian benda kerja yang telah dibuat pada siklus 2 disampaikan pada Tabel 4 .

Tabel 4. Hasil penilaian benda kerja hasil praktik pada siklus 2

\begin{tabular}{ccc}
\hline No & Kelompok & Nilai Rata-Rata \\
\hline 1 & I & 78 \\
2 & II & 76 \\
3 & III & 80 \\
4 & IV & 78 \\
5 & V & 75 \\
\hline & Rerata & 77,4 \\
\hline
\end{tabular}

\section{Refleksi}

Langkah selanjutnya dilakukan refleksi, berdasarkan hasil pengamatan pada siklus 2 tersebut, tampak bahwa sikap dan perilaku mahasiswa mulai mengalami peningkatan. Mahasiswa mulai konsekuen terhadap hasil kegiatan eksplorasi aspek karakter. Mahasiswa sudah mulai fokus dalam bekerja, mahasiswa lebih percaya diri dan tingkat kemandiriannya juga mulai mengalami peningkatan. Dari sisi prestasi juga sudah mulai ada peningkatan.

Untuk mendapatkan kesimpulan yang mantap, maka dilakukan tindakan sekali lagi 
yaitu pada siklus 3. Karena pada siklus 2 sudah mengalami peningkatan, maka tindakan pada siklus 3 mengacu pada tindakan pada siklus 2

\section{Siklus 3}

Rincian tindakan pada siklus 3:

\section{Rancangan Perencanaan}

a. Dosen mempersiapkan materi/job praktik selanjutnya yang akan diberikan pada mahasiswa.

b. Dosen menjelaskan kembali mengenai karakter kerja praktik pemesinan.

2. Rancangan Tindakan

a. Dosen memotivasi dan mengingatkan kembali kepada mahasiswa untuk konsekuen dalam melaksanakan aspek karakter yang sudah dieksplorasi, dalam pelaksanaan praktik.

b. Dosen mempersilahkan mahasiswa untuk melaksanakan praktik, dengan arahan untuk selalu berpedoman pada WPS yang telah disusun dan selalu bekerjasama agar benda kerja yang dihasilkan presisi dan dapat dipasangkan satu dengan lainnya.

c. Pada akhir siklus dosen mengadakan penilaian benda kerja yang telah dibuat dengan melibatkan mahasiswa dalam proses tersebut (dengan menggunakan lembar self assessment).

3. Rancangan Pengamatan

a. Peneliti mengamati sikap dan perilaku mahasiswa selama proses pembelajaran.

b. Mengamati aktivitas mahasiswa pada saat proses self assessment.

Hasil pengamatan sikap dan perilaku mahasiswa selama proses pembelajaran siklus 3 dapat dilihat dalam Tabel 5.

Tabel 5. Hasil pengamatan sikap dan perilaku mahasiswa pada siklus 3

\begin{tabular}{clcc}
\hline No & $\begin{array}{l}\text { Sikap dan perilaku } \\
\text { Mahasiswa }\end{array}$ & $\begin{array}{c}\text { Jumlah } \\
\text { Mahasiswa }\end{array}$ & $\begin{array}{c}\text { Persentase } \\
(\%)\end{array}$ \\
\hline 1 & Disiplin & 16 & 88,8 \\
2 & Tangguh/mandiri & 16 & 88,8 \\
3 & Kerja sama & 18 & 100 \\
4 & Jujur & 18 & 100 \\
\hline \multicolumn{2}{r}{ Rerata } & & 94,4 \\
\hline
\end{tabular}

Hasil penilaian benda kerja yang telah dibuat pada siklus 3, dapat dilihat dalam Tabel 6 berikut ini.

Tabel 6. Hasil penilaian benda kerja hasil praktik pada siklus 3

\begin{tabular}{ccc}
\hline No & Kelompok & Nilai Rata-Rata \\
\hline 1 & I & 90 \\
2 & II & 88 \\
3 & III & 88 \\
4 & IV & 90 \\
5 & V & 86 \\
\hline & Rerata & 88,4 \\
\hline
\end{tabular}

\section{Refleksi}

Berdasarkan hasil pengamatan pada siklus 3 tersebut, tampak bahwa sikap dan perilaku mahasiswa mengalami peningkatan dengan konstan. Mahasiswa konsekuen terhadap hasil kegiatan eksplorasi aspek karakter. Mahasiswa sudah fokus dalam bekerja, mahasiswa lebih percaya diri dan tingkat kemandiriannya juga mengalami peningkatan. Dari sisi prestasi juga mengalami peningkatan yang berarti.

Karena pada siklus 3 ini sudah mengalami peningkatan yang berarti, maka tindakan dihentikan.

Setelah diberikan penjelasan-penjelasan tentang nilai karakter yang harus diterapkan dalam setiap tahapan pembelajaran, maka dapat diamati perubahan tingkah laku mahasiswa selama mengikuti perkuliahan praktik Pemesinan Frais serta prestasi belajar yang telah dicapai. Pengamatan tingkah laku/sikap kerja mahasiswa dilakukan mulai minggu ketiga, karena pada minggu pertama dan kedua baru dilakukan penjelasan-penjelasan tentang prosedur perkuliahan serta nilai-nilai karakter atau sikap yang harus diterapkan oleh mahasiswa. Berdasarkan pengamatan selama 6 minggu mulai dari minggu ke 3 hingga ke 8 (selama 3 siklus), terlihat bahwa perubahan tingkah laku mahasiswa selama pembelajaran praktik sangat positif. Pada siklus 1, terlihat pelaksanaan nilai karakter oleh mahasiswa masih rendah, bila dirata-rata baru sekitar 33,075\% mahasiswa yang melaksanakannya. Mahasiswa belum fokus dalam bekerja, masih 
banyak dijumpai mahasiswa yang menunggu temannya untuk mengerjakan dahulu, dengan kata lain mahasiswa kurang percaya diri dan tingkat kemandiriannya masih rendah. Sepertinya mahasiswa belum menjiwai aspekaspek karakter yang diintegrasikan. Jika dilihat dari penilaian benda kerja hasil praktik, maka hasilnya juga belum memuaskan yaitu nilai rata-rata hanya sekitar 64 . Untuk mengatasi hal tersebut, agar pada siklus 2 terjadi perubahan positif, maka sebelum mahasiswa menyusun WPS, diadakan semacam kegiatan diskusi untuk eksplorasi aspek karakter yang dapat diintegrasikan dalam pembelajaran praktik menurut pendapat mahasiswa.

Pada siklus 2 telah mengalami peningkatan baik sikap kerja maupun prestasi mahasiswa meskipun belum berarti. Tingkah laku atau sikap kerja mahasiswa dalam kaitannya pelaksanaan nilai karakter pada siklus 2, rata-rata sekitar $81,94 \%$ mahasiswa melaksanakan nilai karakter dalam pembelajaran. Sedangkan berdasarkan penilaian prestasi belajar yang dicapai mahasiswa pada siklus 2 ini, rata-rata mencapai nilai 77,4. Berdasarkan data tersebut tampak bahwa sikap dan perilaku mahasiswa mulai mengalami peningkatan yaitu sekitar $48,86 \%$. Mahasiswa mulai konsekuen terhadap hasil kegiatan eksplorasi aspek karakter. Mahasiswa sudah mulai fokus dalam bekerja, mahasiswa lebih percaya diri dan tingkat kemandiriannya juga mulai mengalami peningkatan. Dari sisi prestasi juga sudah mulai ada peningkatan yaitu sekitar 8 point. Untuk mendapatkan kesimpulan yang mantap, maka dilakukan proses tindakan pada siklus 3 .

Pada siklus 3 terjadi peningkatan yang sangat berarti, baik pada sikap kerja mahasiwa yang berimbas juga pada peningkatan prestasi mahasiswa. Pada siklus ini sikap kerja terkait dengan pelaksanaan nilai karakter yaitu sebesar 94,4\% mahasiswa telah melaksanakannya. Hal ini terlihat jelas bahwa pelaksanaan aspek karakter telah mengalami peningkatan 61,325\% dari pelaksanaan pada siklus 1 . Artinya pada siklus 3 ini, mahasiswa telah konsisten dalam melaksanakan aspek karakter dalam proses pembelajaran. Sehingga hal ini berimbas pada meningkatnya prestasi belajar yang dicapai mahasiswa. Pada siklus ini prestasi belajar mahasiswa rata-rata mencapai nilai 88,4 , atau telah mengalami peningkatan sebesar 24,4 point dari prestasi belajar yang dicapai pada siklus 1 . Berdasarkan data-data yang didapatkan tersebut, terbukti bahwa apabila dalam suatu kelas melaksanakan nilai karakter dengan konsisten, maka akan berimbas pada meningkatnya pula prestasi belajar peserta didik dalam kelas tersebut. Hal ini sesuai dengan apa yang telah dihasilkan dalam penelitian yang dilakukan oleh Dr. Marvin Berkowitz dari University of Missouri- St. Louis, menunjukan peningkatan motivasi siswa sekolah dalam meraih prestasi akademik pada sekolah-sekolah yang menerapkan pendidikan karakter. Kelaskelas yang secara komprehensif terlibat dalam pendidikan karakter menunjukkan adanya penurunan drastis pada perilaku negatif siswa yang dapat menghambat keberhasilan akademik.

\section{SIMPULAN}

Sikap dan perilaku mahasiswa setelah menerapkan model pembelajaran CBT berbasis karakter dalam proses pembelajaran praktik pemesinan frais mengalami peningkatan yaitu rata-rata sebesar $30,66 \%$. Prestasi belajar mahasiswa setelah menerapkan model pembelajaran CBT berbasis karakter dalam proses pembelajaran praktik pemesinan frais juga mengalami peningkatan rata-rata sebesar $17,55 \%$.

\section{DAFTAR RUJUKAN}

Darmiyati Zuhdi, Komarudin Hidayat, dkk. (2009). Grand Design dan Nilai-Nilai Target Pendidikan Karakter. Yogyakarta: UNY Press.

Dedi Supriyadi, dkk. (2001) Reformasi Pendidikan Dalam Konteks Otonomi 
126 Jurnal Dinamika Vokasional Teknik Mesin, Volume 2, Nomor 2, Oktober 2017

Daerah., Yogyakarta: Adicita Karya Nusa.

Depdiknas. (2002). Konsep Pendidikan Berorienatsi Kecakapan Hidup (Life skill) Melalui Pendekatan Pendidikan Berbasis Kelas (Broad Base Education$B B E)$. Jakarta: Depdiknas.

Gonczi, A. (1998). Developing a competent workforce: Adult training strategies for vocational educators and trainers. Leadbrook SA: National Centre for Vocational Education Research Ltd.
Marihot Manullang. (2009). Grand Design Pendidikan Karakter Bangsa. Diambil dari: http://hariansib.com

Sidik Purnomo. (2009). Prinsip Pembelajaran Berbasis Kompetensi . Diambil dari http://kidispur.blogspot.com/prinsippembelajaran-berbasis.html, pada tanggal 22 April 2009.

UU No 20 Tahun 2003 Tentang Sistem Pendidikan Nasional.

Kamus Besar Bahasa Indonesia. Jakarta : Balai Pustaka. 